\title{
Determinants of a Pre-Treatment Model in Achieving Economic and Environmental Sustainability in Membrane Desalination
}

\author{
(Penentu Model Pra-Rawatan untuk Mencapai Kemampanan Ekonomi dan Alam Sekitar dalam \\ Penyahgaraman Membran) \\ Man Djun Lee*, Sebastian Dayou \& Prashobh Karunakaran \\ School of Engineering and Technology, University College of Technology Sarawak, Sarawak, \\ Malaysia
}

\begin{abstract}
Feedwater pre-treatment plays a significant role in the production performance of water desalination operations. This study aims to formulate a pre-treatment model to evaluate the determinants in achieving economic and environmental sustainability. The research is oriented toward the goal of productivity and performance improvement in the water desalination process. The main objective of this study was to better understand the relationship between feedwater pre-treatment and demineralised water production. The secondary objective was to investigate the effect of an ultrafiltration membrane (UFM) on feedwater production performance. Case studies and literature review are included in this paper. Factors that potentially hinder the efficiency and reduce the load capacity of the desalination process include sand, high levels of ionic bond, biomass and colloid materials. These fouling factors could be eliminated efficiently from the feedwater during pre-treatment. Results demonstrated that the contribution of all inputs to achieve targeted pre-treated water quality $(S D I<3)$ was significant $(p<$ 0.05 ) except for activated carbon. Investigations of the pre-treatment process have shown that the silt density index (SDI) is reduced by 45\% using a UFM. Higher performance in water desalination was achieved through a higher efficiency in the removal of bacteria, sand, biomass and natural organic materials. Economic analysis showed that overall capacity utilization and operating performance had increased by 11\%. This study concludes that quality pre-treatment is essential for achieving higher performance in membrane desalination operations.
\end{abstract}

Keywords: Membrane desalination; pre-treatment technology; economic and environmental sustainability

ABSTRAK

Pra-rawatan air sebelum dinyahgaramkan memainkan peranan penting dalam prestasi pengeluaran dalam operasi penyahgaraman air. Kajian ini bertujuan untuk merumuskan model pra-rawatan untuk menilai penentu untuk mencapai kemampanan ekonomi dan persekitaran. Kajian ini dirumuskan dengan peningkatan produktiviti dan prestasi proses penyahgaraman air. Kepentingan utama adalah untuk meningkatkan pemahaman tentang hubungan antara air pra-rawatan dan pengeluaran air demineralisasi. Objektif sekunder kajian ini adalah untuk mengkaji kesan membran ultra penapisan (UFM) untuk meningkatkan prestasi pengeluaran air. Kajian kes dan kajian karya adalah sumber maklumat dalam kajian ini. Faktor-faktor yang menjejaskan potensi yang menghalang kecekapan dan mengurangkan penggunaan kapasiti proses penyahgaraman seperti pasir, ikatan ionik tinggi, biomas dan bahan koloid. Keputusan menunjukkan bahawa sumbangan semua input untuk mencapai kualiti air yang disasarkan (SDI <3) yang disasarkan adalah signifikan $(p<0.05)$ kecuali karbon aktif. Penyiasatan ini mengenai proses pra-rawatan telah menunjukkan bahawa indeks kepadatan lumpur (SDI) dapat dikurangkan sebanyak 45\% dengan menggunakan membran penapis ultra. Prestasi tinggi dalam penyahgaraman air dicapai kerana kecekapan penyingkiran bakteria, pasir, biomas dan bahan organik semula jadi. Sebaliknya, keputusan analisis ekonomi menunjukkan bahawa penggunaan kapasiti secara keseluruhan dan prestasi operasi industri kes telah meningkat sebanyak $11 \%$. Kajian ini menyimpulkan bahawa pra-rawatan kualiti adalah penting untuk mencapai prestasi yang lebih tinggi dalam operasi penyahgarapan membran.

Kata kunci: Penyahgaraman membran; pra-rawatan air; kemampanan ekonomi dan persekitaran

\section{INTRODUCTION}

Desalination technology has developed extensively during the last 50 years to produce freshwater from saline water.
At its initial stage, the fresh water production process was thermally-based and not feasible economically or environmentally. Membrane technology has received more interest than thermal desalination due to its lower cost, higher 
efficiency and lessened negative environmental impact (Brunetti et al. 2015). In terms of energy consumption, membrane technology is a cheaper and "greener" option than thermal desalination even though membrane technology is a pressure-intensive water production process. Better pump design and the use of energy recovery devices reduce the electrical energy consumption for membrane technology (Drak \& Adato 2014). The productivity and performance of membrane technology depend on the pre-treatment quality of feedwater. The known factors for membrane fouling are sand, a higher degree of ionic bond, biomass including algae, pollutants and colloid material concentrations in the intake water (Anjum et al. 2016).

Feedwater pre-treatment has long been an important production performance issue in the membrane desalination process, especially for open intake systems such as river or sea water. This is because the ineffective pre-treatment of feedwater causes higher operating pressure and increases the membrane cleaning frequency. Indeed, inefficient pretreatment reduces the membrane operating life and capacity utilization (CU) of plant machinery. Ineffective pre-treatment is associated with five specific types of membrane fouling: particulate fouling, scaling, bio-fouling, organic and colloidal fouling. Fundamentally, feedwater is the source of membrane fouling. Therefore, the efficiency of the pre-treatment process is vital for membrane desalination production performance (Ang et al. 2016). Pre-treatment for desalination is a challenging issue and will likely continue to be the dominant challenge in designing water desalination plants to a targeted performance. The literature has reported that brackish saline water quality is not stable and its salinity fluctuates greatly. For this reason, water industries are struggling to establish a standard pre-treatment model. Nowadays, pre-treatment plants are, indeed, site-specific and depend on feedwater constituents. It appears that accessing historical intake quality data and conducting pilot testing are key to designing an efficient pre-treatment plant (Malaeb et al. 2011). Brackish saline water is a major water source, but its constituents are predominantly dependent on geographical and environmental conditions. However, pre-treatment of intake that is a mixture of brackish water and city-polluted water (BWCP) of mediumlevel salinity and used for producing demineralized water (DW) is not reported in the literature. Indeed, the effect of
BWCP on CU of DW production machinery is also not available in the published literature. To fill this gap in the research, pretreatment of BWCP for DW production has been undertaken.

This research project aims to evaluate the operating performance of BWCP pre-treatment for economic and environmental sustainability. Specifically, this study is designed to evaluate the statistical relationship among the desalination system operating variables to identify those inputs that could possibly contribute to significantly reduced SDI to improve pre-treatment performance and achieve higher CU. This study also evaluates the impact on the economic and environmental sustainability of using an ultrafiltration membrane (UFM) in a desalination process.

The novelty of this work is the development of a feedwater pre-treatment model to produce demineralized water for the pharmaceutical industry with the aid of a statistical tool to identify significance of inputs. Additionally, a UFM was used in the pre-treatment process to evaluate the $\mathrm{CU}$ and economic performance of the desalination plant.

\section{LITERATURE REVIEW}

Plant production performance is positively correlated with labor skills, level of process technology and working environment (Lee et al. 2016; Shahidul \& Shazali 2011). Likewise, higher (CU) of chemical-based process systems contributes to increased environmental sustainability (Ting et al. 2013). Clearly, for achieving a higher degree of CU, plant technology must be used efficiently (Shahidul et al. 2013), since it is the determinant for achieving higher productivity and performance (Shahidul et al. 2011). Water desalination plant production performance depends on key operating factors such as preventive maintenance of machinery and feedwater quality. Silt density index (SDI) is an indicator of membrane feedwater quality (Kang et al. 2016). The production performance of the desalination plant also depends on fouling and scaling behavior of the membrane. By governing the pre-treatment process, SDI could be enhanced to a sustainable level (Alawadhi, 1997). The five types of membrane fouling are listed in Table 1 (Anjum et al. 2016; Imbrogno, Keating, Kilduff \& Belfort 2016; Kang et al. 2016; Monnot, Laborie \& Cabassud 2016; Sahachaiyunta, Koo \& Sheikholeslami 2002).

TABLE 1. Typical membranes fouling and solutions

\begin{tabular}{lll}
\hline Membrane Fouling & \multicolumn{1}{c}{ Cause } & \multicolumn{1}{c}{ Solutions } \\
\hline Biological fouling & Bacteria, microorganism, viruses and protozoan & Chlorination \\
Particle fouling & Sand, clay (turbidity, suspended solids) & Filtration \\
Colloidal fouling & Organic and inorganic complex, colloidal particles and \\
microalgae & $\begin{array}{l}\text { Coagulation, filtration, flocculation/ } \\
\text { Sedimentation }\end{array}$ \\
Organic fouling & Natural organic matter, humic acid and fulvic acid and \\
& biopolymer & $\begin{array}{l}\text { Coagulation, ultra-filtration, activated } \\
\text { carbon }\end{array}$ \\
Mineral fouling & Calcium, magnesium, Barium sulfates and carbonate & Anti-sealant dosing and acid dosing \\
Oxidant fouling & Chlorine, ozone and $\mathrm{KMnO}_{4}$ & $\begin{array}{l}\text { Sodium bi-sulfate dosing, Activated } \\
\text { carbon }\end{array}$ \\
\hline
\end{tabular}




\section{MEMBRANE BIO-FOULING AND SOLUTIONS}

Surface water contains various microorganisms such as bacteria and protozoa that contribute to biofilm formation on the membrane surface and grow if carbon source and nutrients are available (Monnot et al. 2016). Killing bacteria and microorganisms before the water enters the membrane is essential to prevent bio-fouling. A very cost-effective way to avoid biological fouling is chlorination but chlorine oxidizes the membrane material and the majority of available membranes can only tolerate 1000 ppm chlorine (Belila et al. 2016). The typical chlorine dose is about $3 \mathrm{mg} / \mathrm{L}$ of active chlorine. A common de-chlorination process is the injection of sodium bisulfite or meta-bisulfite, classified as chlorine scavengers, but this process contributes to environmental problems (Dawoud \& Mulla 2012). At most large-scale desalination plants, electro-chlorination is being used to produce sodium hypochlorite $(\mathrm{NaOCl})$ from the excess of sodium chloride salt $(\mathrm{NaCl})$ present in seawater. For the efficient use of active chlorine to produce $\mathrm{NaOCl}$, the $\mathrm{pH}$ should be between 5.5 and 6.5 (Avlonitis et al. 2003).

\section{MEMBRANE PARTICULATE AND NATURAL FOULING AND} SOLUTION

Natural organic materials (NOM) are present in all sources of water including seawater. One type of particulate fouling refers to the deposition of various materials such as organics, suspended matter and colloids on the high-pressure side of the membrane, building up a thin film on the membrane surface. Particulate fouling is a persistent problem in most membranes and a secondary problem arising from this is a reduction in water production, which translates into increased operating costs (Kang et al. 2016). Reliable methods of preventing particulate fouling employ efficient pre-treatment processes prior to membrane filtration. The characteristics of each raw water source such as salinity, total suspended solids, total dissolved solids and other pollutants are different and require a custom approach (Zaiedy, Karim $\&$ Mutalib 2016). This particulate material can be removed through gravity filter media with a coagulation process. To measure the degree of this fouling problem, silt density index (SDI) is used as described in American Society for Testing and Materials (ASTM) 4189-95. To achieve high economic operating efficiency, the SDI limit should be maintained at less than 3 (SDI < 3) (Monnot et al. 2016). Membrane cleaning is essential in achieving better production performance but will contribute to increased machinery downtime, energy and chemical use.

Sources of NOM include pollutants with carboxyl and hydroxyl functional groups (Woo et al. 2015). NOM is considered a major contributor to membrane fouling in a desalination process and can significantly reduce production performance and membrane life and increase operating costs (Ju et al. 2015). Understanding fouling mechanisms and developing ways to control them are critical to the economy of desalination technology. Ferric chloride $\left(\mathrm{FeCl}_{3}\right)$ dosing in the pre-treatment phase is an effective way of removing organic compounds from feedwater. The coagulation by $\mathrm{FeCl}_{3}$ at optimum dosage removed about $95 \%$ of hydrophobic compounds. The application of a UFM in pre-treatment has also shown an extremely good result (Löwenberg et al. 2015).

\section{MINERAL FOULING AND SOLUTION}

Mineral fouling of membranes is predominantly composed of divalent metal ions. Monovalent metals such as sodium and potassium are nearly completely soluble, whereas in the presence of sulfate, phosphate or carbonate, divalent ions such as calcium, iron, magnesium, barium, strontium, radium, beryllium, lead and silicon are nearly insoluble. These molecules precipitate on the membrane surface and form crystals. Common forms of mineral scale are calcium carbonate, calcium sulfate, calcium, phosphate, barium sulfate, strontium sulfate, iron hydroxide and silicon dioxide (silica) (Sahachaiyunta et al. 2002). To prevent mineral fouling, a small but significant dosage of anti-scalants are being used to reduce the mineral fouling threat (Zhu et al. 2009).

\section{OXIDANT FOULING AND SOLUTION}

Chlorine and its associated products have been used for many years to destroy various of microorganisms. Usually, feedwater passes through a series of dedicated water pretreatment equipment before being fed into the membrane. To reduce the membrane bio-fouling threat, free residual chlorine concentrations of $0.50 \mathrm{mg} / \mathrm{L}$ to $1.0 \mathrm{mg} / \mathrm{L}$ have been maintained through the entire pre-treatment line (Belila et al. 2016). When the chlorinated water of such concentrations feed into the filtration membrane, the membrane's structural materials will degrade. Common chemicals that could cause significant damage to membrane materials include chlorine dioxide, hydrogen peroxide, ozone and permanganate. The desalination process should be carried out under acidic conditions $(5.5<\mathrm{pH}<6.5)$ to remove free chlorine (Belila et al. 2016).

\section{METHODOLOGY}

Extensive literature review on pre-treatment of membrane desalination along with operating data on the membrane process of a case study desalination plant is the basis of this study. The theoretical framework of this research was developed from published studies in the relevant field. The production performance models have been evaluated using operating data of the water desalination processes in the case study. Two sets of data have been collected directly from the operating logbooks of the plant operation. The first data set 
of this study is derived from the plant operation without the use of UFM; the second is with UFM.

\section{DESCRIPTION OF CASE STUDY PLANT}

The case study plant for this research has a long history in pharmaceuticals production and demineralized water (DW) is a basic ingredient in the production process. At the case study site, DW is being produced and pre-treatment is considered a determinant of DW quality. It is evident from historical data of the plant that pre-treatment has been used to reduce membrane fouling to maximize machinery $\mathrm{CU}$. The plant capacity in this study is $1500 \mathrm{~L} / \mathrm{hr}$. The membrane module used is AG4040F produced by GE Osmonics and has been installed to produce DW. At the beginning of the first two years of operation, the plant had been using conventional pre-treatment to produce feedwater for the membrane but performance was not significant. Finally, UFM was installed at the end of the pre-treatment process to improve plant performance. The results are presented in a later section.

\section{THEORETICAL FRAMEWORK}

Scaling and fouling on high-pressure sides of membranes create resistance to membrane permeation (freshwater production). The thickness of the scale and degree of fouling in membranes are determinants of feedwater quality and utility for desalination (Ang et al. 2016). Declining water production rate is an indicator of scale formation on the membrane surface and fouling of membrane materials. The theoretical framework for this study is detailed in Table 2 . The performance indicators employed in this study were to determine the degree of sustainability.

TABLE 2. Theoretical framework employed in this study

\begin{tabular}{|c|c|c|}
\hline $\begin{array}{l}\text { Performance } \\
\text { Indicators }\end{array}$ & Mathematical Expressions & References \\
\hline $\begin{array}{l}\text { Plant Capacity } \\
\text { Utilization (CU) }\end{array}$ & $\mathrm{CU}=\frac{\text { Actual Output }\left(\mathrm{Q}_{\mathrm{A}}\right)}{\text { Potential Qutput }\left(\mathrm{Q}_{\mathrm{P}}\right)}$ & $\begin{array}{l}\text { Lee, Djubair \& Ngu 2017; } \\
\text { Shahidul et al. } 2014\end{array}$ \\
\hline Production Cost & $\begin{array}{l}C p=\frac{c f}{t_{n Q}} \mathrm{CP} \text { - machine permeate cost per liter of permeate, } c f= \\
\text { membrane cost per square meter, } t_{n}=\text { operating time } / \mathrm{hr}, n=\text { module life } \\
\text { expectance } Q=\text { permeation rate }\end{array}$ & $\begin{array}{l}\text { Al-Karaghouli \& Kazmerski } \\
\text { 2013; Lee et al. } 2016\end{array}$ \\
\hline $\begin{array}{l}\text { Cost Benefit } \\
\mathrm{R}(\mathrm{B} / \mathrm{C})\end{array}$ & $R(B / C)=\frac{\text { total benefit }}{\text { total cost }}$ & Al-Najjar \& Alsyouf 2004 \\
\hline $\begin{array}{l}\text { Plant Operating } \\
\text { Reliability, } \mathrm{R}(\mathrm{t})\end{array}$ & $\propto=$ failure rate of machine, $t=$ failure time & $\begin{array}{l}\text { Das, Lashkari \& } \\
\text { Sengupta } 2007\end{array}$ \\
\hline $\begin{array}{l}\text { Plant Economic } \\
\text { Efficiency }\end{array}$ & Economic Efficiency, $\eta E C=\frac{\text { Value of system output }}{\text { Value of system Input }}$ & Saeed \& Khan 2007 \\
\hline $\begin{array}{l}\text { Slid density Index } \\
\text { (SDI) }\end{array}$ & $\mathrm{SD} / I 15=\frac{\left[1-\frac{t_{i}}{t_{f}}\right] \cdot 100}{T} \quad \mathrm{~T}=$ Elapsed time, $\mathrm{t}_{\mathrm{i}}=$ Initial time, $\mathrm{t}_{\mathrm{f}}=$ final time & $\begin{array}{l}\text { Kang et al. 2016; } \\
\text { Monnot et al. } 2016\end{array}$ \\
\hline $\begin{array}{l}\text { Plant availability, } \\
\mathrm{A}(\mathrm{t})\end{array}$ & $\begin{array}{l}\mathrm{A}(\mathrm{t})=\frac{T(d o p)-t(d)}{T d o p}, \mathrm{~T}(\mathrm{dop}) \text {-design operating time, td-down time for } \\
\text { maintenance }\end{array}$ & $\begin{array}{l}\text { Ghaffour, Missimer \& } \\
\text { Amy } 2013\end{array}$ \\
\hline
\end{tabular}

At pre-treatment, six potential operating variables were used to produce high quality feedwater to the membrane $(\mathrm{SDI}<3)$. The main objective was to measure the degree of contribution of variables in producing the desired feedwater. Input-output data over four operating years were analyzed using the Statistical Package for the Social Sciences (SPSS) Software. The findings of the analysis are listed in Table 3.
Results demonstrated that the contribution of all inputs to achieve targeted pre-treated water quality (SDI $<3$ ) was significant $(p<0.05)$ except for activated carbon. This is due to the fact that the amount of activated carbon needed for effective pre-treatment is relatively high compared to other determinants (Parthasarathy et al. 2016). Although activated carbon can be reused for the second batch of feedwater, if 
TABLE 3. Statistical validation of case industry plant operations

\begin{tabular}{cccc}
\hline Independent variables & Inputs to outputs Coefficient $(\beta)$ & Pearson Correlation $(\mathrm{r})$ & Significance Test $(\mathrm{p}$-value $)$ \\
\hline Bioreactor Tank Height & 0.34 & 0.54 & $0.00^{*}$ \\
Sedimentation Time & 0.29 & 0.62 & $0.00^{*}$ \\
$\mathrm{FeCl}_{3}$ & 0.31 & 0.49 & $0.001^{*}$ \\
Activated Carbon & 0.01 & 0.15 & 0.29 \\
Fine Sand Filter & 0.02 & 0.18 & $0.01^{*}$ \\
UFM & 0.31 & 0.68 & $0.01^{*}$ \\
\hline
\end{tabular}

the recycling of activated carbon is not done properly, it will contribute to fouling of the UFM hence reducing overall production performance. It was also evident that the SDI index of pre-treated water and contributions of all operating variables were positively correlated $(r>0)$. This finding indicates that using activated carbon for pre-treatment is not feasible.

\section{SUSTAINABILITY ANALYSIS OF PLANT OPERATION}

Models describing DW production performance were developed employing the input-output data obtained from the case study plant operation. Cleaning and normalization techniques were applied to the input-output data using statistical software SPSS. The analysis of the outputs generated by SPSS software is listed in Table 4.

Findings indicated that operating parameters of pretreatment with a UFM were higher compared to operations without a UFM. These findings demonstrated that performance of pre-treatment is significantly improved with the use of a UFM in removing particulate and colloid materials from feedwater. The results demonstrated that use of a UFM contributed to an approximate $18 \%$ reduction in chemical use and was a step toward achieving environmental sustainability. The output of DW with respect to feedwater from pre-treatment is depicted in Figure 1 and indicates that the economic performance with a UFM was superior to that using a conventional process.

TABLE 4. Plant operating performance

\begin{tabular}{|c|c|c|c|c|}
\hline $\begin{array}{l}\text { Performance } \\
\text { Parameters }\end{array}$ & $\begin{array}{l}\text { Performance without } \\
\text { UFM }\end{array}$ & $\begin{array}{l}\text { Performance with } \\
\text { UFM }\end{array}$ & Sustainability Index & Comment \\
\hline $\mathrm{CU}$ & $62 \%$ & $73 \%$ & $11 \%$ Increase & Achievement is Significant \\
\hline$\eta_{\mathrm{EC}}$ & 1.12 & 1.34 & $>1$ & Improvement is sustainable \\
\hline $\mathrm{R}_{\mathrm{b} / \mathrm{c}}$ & 1.1 & 1.22 & $>1$ & UFM is economically feasible \\
\hline $\mathrm{Q} / \mathrm{m}^{2}-\mathrm{hr}$ & 650 liters & 723 liters & $11 \%$ Increase & Achievement is Significant \\
\hline $\mathrm{SDI}_{15}$ & 3.2 & 2.75 & $45 \%$ Increase & Achievement is Significant \\
\hline $\mathrm{T}_{\mathrm{d}}$ & $22 \%$ & $15 \%$ & $7 \%$ Decrease & Achievement is Significant \\
\hline$A(t)$ & $64 \%$ & $72 \%$ & $8 \%$ Increase & Achievement is Significant \\
\hline $\mathrm{R}(\mathrm{t})$ & 0.65 & 0.74 & $9 \%$ Increase & Achievement is Significant \\
\hline $\mathrm{FeCl}_{3}$ & $3.1 \mathrm{mg} / 1$ & $2.55 \mathrm{mg} / \mathrm{l}$ & 18\% Less Chemical & Achievement is Significant \\
\hline
\end{tabular}

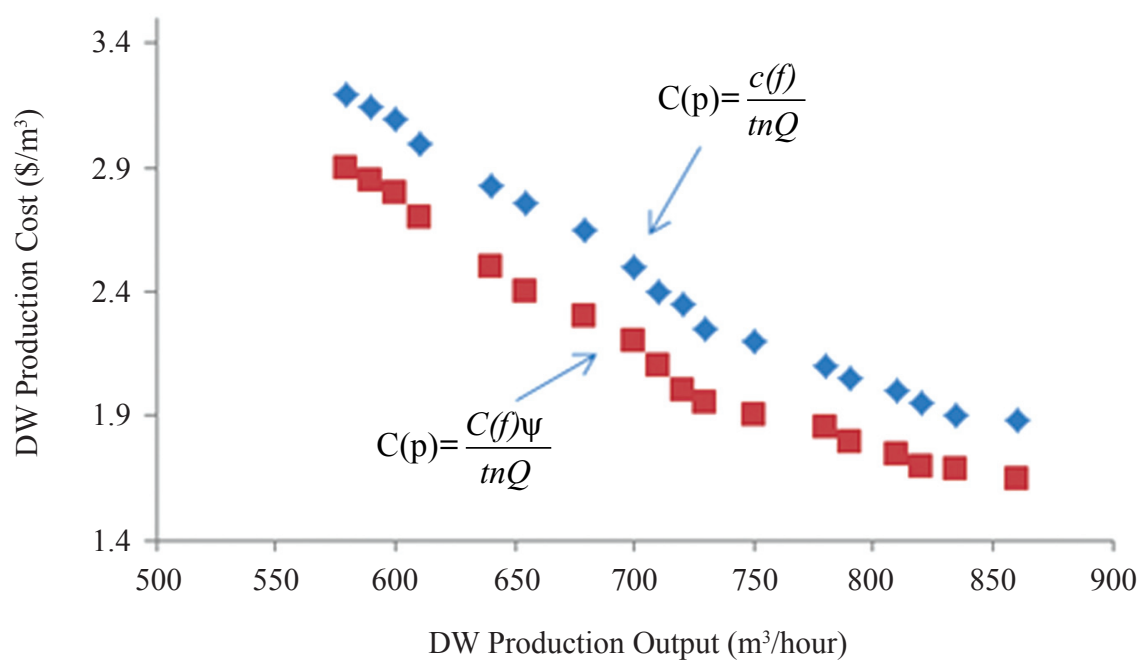

FIGURE 1. Economic analysis of plant operation 
DISCUSSION

Nine models (Table 2) relating to economic and environmental sustainability were employed in this study. Analysis of the findings demonstrates that using the UFM in desalination pre-treatment plants is associated with improved economic and environmental sustainability. When reducing chemical consumption using $\mathrm{FeCl}_{3}$, it is advisable to allow more time for sedimentation. Results indicate that the sedimentation time and height of the bioreactor show a positive correlation with SDI 15 and were significant at the $95 \%$ confidence level $(p<0.05)$. The contribution of a UFM to obtaining targeted SDI was significant $(\mathrm{p}<0.05)$, while the contribution of activated carbon was insignificant $(p>0.05)$. The economic analysis demonstrates that using a UFM in the process improves economic sustainability of the plant. Figure 2 has also confirmed that a UFM contributes to increased production performance, cost reduction and greater environmental sustainability by reducing chemical consumption by about $18 \%$.

\section{CONCLUSION}

In this study, a desalination pre-treatment model to evaluate the economic and environmental sustainability was formulated. This study also proposed an environmentally friendly and cost-effective method for desalination pretreatment. This method is designed to reduce the main fouling factors associated with feedwater. The proposed pre-treatment method would be a sustainable alternative to chemically intensive pre-treatment in removing particulate, microbial and organic micro-pollutants. It is robust, reduces the dosage of inorganic coagulant (ferric chloride) and requires little maintenance. This method can be retro-fitted to existing plants and will contribute to a reduced carbon footprint while achieving economic and environmental sustainability. Research findings conclude that a UFM in desalination pretreatment is useful in the achieving greater economic and environmental sustainability.

\section{REFERENCES}

Al-Karaghouli, A. \& Kazmerski, L. L. 2013. Energy consumption and water production cost of conventional and renewable-energy-powered desalination processes. Renewable and Sustainable Energy Reviews 24: 343356.

Al-Najjar, B. \& Alsyouf, I. 2004. Enhancing a company's profitability and competitiveness using integrated vibration-based maintenance: A case study. European Journal of Operational Research 157(3): 643-657.

Alawadhi, A. A. 1997. Pretreatment plant design - key to a successful reverse osmosis desalination plant. Desalination 110(1-2): 1-10.
Amy, G., Ghaffour, N., Li, Z., Francis, L., Linares, R. V., Missimer, T. \& Lattemann, S. 2016. Membrane-based seawater desalination: Present and future prospects. Desalination 401: 16-21.

Ang, W. L., Nordin, D., Mohammad, A. W., Benamor, A. \& Hilal, N. 2016. Effect of membrane performance including fouling on cost optimization in brackish water desalination process. Chemical Engineering Research and Design 117:401-413.

Anjum, M., Miandad, R., Waqas, M., Gehany, F. \& Barakat, M. A. 2016. Remediation of wastewater using various nano-materials. Arabian Journal of Chemistry, 1-23.

Avlonitis, S. A., Kouroumbas, K. \& Vlachakis, N. 2003. Energy consumption and membrane replacement cost for seawater RO desalination plants. Desalination 157(1-3): 151-158.

Belila, A., El-Chakhtoura, J., Otaibi, N., Muyzer, G., Gonzalez-Gil, G., Saikaly, P. E. \& Vrouwenvelder, J. S. 2016. Bacterial community structure and variation in a full-scale seawater desalination plant for drinking water production. Water Research 94: 62-72.

Brunetti, A., Macedonio, F., Barbieri, G. \& Drioli, E. 2015. Membrane engineering for environmental protection and sustainable industrial growth: Options for water and gas treatment. Environmental Engineering Research 20(4): 307-328.

Das, K., Lashkari, R. S. \& Sengupta, S. 2007. Machine reliability and preventive maintenance planning for cellular manufacturing system. European Journal of Operational Research 183(1): 162-180.

Dawoud, M. A. \& Mulla, M. M. Al. 2012. Environmental impacts of seawater desalination: arabian gulf case study. International Journal of Environment and Sustainability 1(3): 22-37.

Drak, A. \& Adato, M. 2014. Energy recovery consideration in brackish water desalination. Desalination 339(1): 34-39.

Ghaffour, N., Missimer, T. M. \& Amy, G. L. 2013. Technical review and evaluation of the economics of water desalination: Current and future challenges for better water supply sustainability. Desalination 309: $197-$ 207.

Imbrogno, J., Keating, J. J., Kilduff, J. \& Belfort, G. 2016. Critical aspects of $\mathrm{RO}$ desalination: A combination strategy. Desalination 401: 68-87.

Ju, Y., Hong, I. \& Hong, S. 2015. Multiple MFI measurements for the evaluation of organic fouling in SWRO desalination. Desalination 365: 136-143.

Kang, J.-S., Sung, S. C., Lee, J. J. \& Kim, H.-S. 2016. Application of ceramic membrane for seawater desalination pretreatment. Desalination and Water Treatment 57(55): 26700-26705.

Lee, M. D., Djubair, R. A. \& Ngu, H. J. 2017. Sustainability Paradigm for Malaysian Manufacturing SMEs: An Operations Research Approach. International Journal of Business and Technopreneurship 7(3): 355-368. 
Lee, M. D., Elaswad, H., Yassin, A. \& Syed, S. T. 2016. Operations research method in engineering projects. International Journal of Advanced Engineering Research and Application 2(2): 48-64.

Lee, M. D., Houssein, M. A. E. \& Shahidul, M. I. 2016. Production machinery maintenance cost optimization: A Review. International Journal of Advanced Engineering Research and Application 2(3): 131-146.

Löwenberg, J., Baum, J. A., Zimmermann, Y. S., Groot, C., van den Broek, W. \& Wintgens, T. 2015. Comparison of pre-treatment technologies towards improving reverse osmosis desalination of cooling tower blow down. Desalination 357: 140-149.

Malaeb, L. \& Ayoub, G. M. 2011. Reverse osmosis technology for water treatment: State of the art review. Desalination 267: 1-8.

Monnot, M., Laborie, S. \& Cabassud, C. 2016. Granular activated carbon filtration plus ultrafiltration as a pretreatment to seawater desalination lines: Impact on water quality and UF fouling. Desalination 383(April): $1-11$.

Parthasarathy, S., Mohammed, R. R., Fong, C. M., Gomes, R. L. \& Manickam, S. 2016. A novel hybrid approach of activated carbon and ultrasound cavitation for the intensification of palm oil mill effluent (POME) polishing. Journal of Cleaner Production 112: 1218 1226.

Saeed, M. \& Khan, N. A. 2007. Measurement of economic efficiency. Journal of Agriculture 23(1): 197-206.

Sahachaiyunta, P., Koo, T. \& Sheikholeslami, R. 2002. Effect of several inorganic species on silica fouling in RO membranes. Desalination 144(1-3): 373-378.

Shahidul, M. I., Osman, M. S., Syed Shahzali, S. T., Yassin, A., Ting, C. H., Hishamuddin, A. H. \& Adzlan, A. F. K. 2013. Measuring production capacity utilization and its impact on manufacturing performance and environment. Proceeding in $6^{\text {th }}$ Energy and Environment Engineering Conference 2013, $1^{\text {st }}$ to $4^{\text {th }}$ July 2013, Kuching, Sarawak.

Shahidul, M. I., Shazali, S. T. S., Abdullah, Y., Ting, C. T., Lee, M. D., Hishamuddin, A. H. \& Adzlan, A. F. K. 2014. Determinants of desalination machinery capacity utilization: evaluate in the aspect of energy, environment and economic sustainability. In Advances in Process Engineering \& Green Energy. Kuching: EnCon.
Shahidul, M. I., Shazali, S. T. S. \& Syed Shazali, S. T. 2011. Dynamics of manufacturing productivity: lesson learnt from labor intensive industries. Journal of Manufacturing Technology Management 22(5): 664-678.

Ting, C. H., Shahidul, M. I., Shazali, S. T. S. \& Abdullah, Y. 2013. Measuring Contextual Impact of Maintenance on Machinery Capacity Utilization and Environment. In $6^{\text {th }}$ Engineering Conference. Kuching, Sarawak.

Woo, Y. C., Lee, J. J., Tijing, L. D., Shon, H. K., Yao, M. \& Kim, H.-S. S. 2015. Characteristics of membrane fouling by consecutive chemical cleaning in pressurized ultrafiltration as pre-treatment of seawater desalination. Desalination 369: 510-61.

Zaiedy, N. I., Karim, O. A. \& Mutalib, N. A. A. 2016. Water quality of surface runoff in Loop Two catchment area in UKM. Jurnal Kejuruteraan 28: 65-72.

Zhu, A., Christofides, P. D. \& Cohen, Y. 2009. Effect of thermodynamic restriction on energy cost Optimization of RO membrane water desalination. Industrial and Engineering Chemistry Research 48(13): 6010-6021.

*Man Djun Lee

Sebasttian Dayou

Prashobh Karunakaran

School of Engineering and Technology

University College of Technology Sarawak

96000 Sibu, Sarawak, Malaysia.

*Corresponding author; e-mail: man.djun@ucts.edu.my

Received date: $26^{\text {th }}$ September 2017

Accepted date: $5^{\text {th }}$ April 2018

Online First date: $1^{\text {st }}$ September 2018

Published date: $31^{\text {st }}$ October 2018 